\title{
PENYELARASAN ANTARA PERMINTAAN DENGAN PENYEDIAAN GURU PRODUKTIF BERDASARKAN SPEKTRUM KEAHLIAN DI SMK DALAM PERSPEKTIF DESENTRALISASI PENDIDIKAN
}

\author{
A.G Tamrin \\ Prodi. Pend. Teknik Informatika dan Komputer, Jurusan Pendidikan Teknik dan Kejuruan, FKIP, UNS \\ Kampus UNS Pabelan Jl. Ahmad Yani 200, Surakarta, Telp/Fax 0271718419 \\ E-Mail: agthamrin2@yahoo.com
}

\begin{abstract}
Structuring expertise with the rising spectrum of competence and skill development of the ratio between the SMA: SMK is 30 SMA : 70 SMK has consequences on the fulfillment of teachers in vocational productive. Teachers' needs for productive subjects did in fact still not be met by LPTK and become increasingly difficult to meet due to teachers earning the required majority has not been organized by LPTK. The need for truly productive teachers perceived as an obstacle difficult to solve in the area. For that, the necessary alignment between demand with the supply of teachers by utilizing the model teacher's certification activities and cooperation between LPTK with Non LPTK with Local Government done with synergize the availability of customize and can be generated LPTK teacher and scholar who produced non LPTK but the field of knowledge in accordance with the requirements SMK.
\end{abstract}

Kata Kunci: Penyelarasan, Permintaan, Penyediaan, Guru Produktif, Spektrum Keahlian SMK, Desentralisasi Pendidikan.

\section{PENDAHULUAN}

Pembangunan nasional Indonesia akan berhasil dengan baik bila tersedia sumber daya manusia yang berkualitas dalam mengoptimalkan dan memaksimalkan perkembangan seluruh dimensi pembangunan. Sumberdaya yang berkualitas dapat diupayakan melalui pendidikan, baik melalui jalur pendidikan formal maupun non formal. Satuan pendidikan pada jenjang pendidikan formal yang bertujuan menyiapkan lulusannya terutama untuk memiliki keunggulan di dunia kerja adalah Sekolah Menengah Kejuruan (SMK).

Menurut UU Sistem Pendidikan Nasional No. 20 Tahun 2003 pasal 18 dan pasal 15, SMK termasuk pada "satuan pendidikan menengah kejuruan sebagai lanjutan dari pendidikan dasar yang bertujuan mempersiapkan peserta didik terutama dalam bidang pekerjaan tertentu". SMK dirancang untuk menyiapkan peserta didik atau lulusan yang siap memasuki dunia kerja dan mampu mengembangkan sikap profesional di bidang pekerjaannya. Oleh karena itu, lulusan SMK harus selalu dekat dengan dunia kerja, (Djojonegoro, 1998: 34).

Meningkatnya persaingan global dalam abad ke-21 yang merupakan abad berkembangnya ilmu pengetahuan dengan pesat (Tilaar, 2004: 39), mengharuskan SMK berkembang mengikuti arah perkembangan dunia kerja, sehingga SMK perlu melakukan penyesuaian pada kompetensi keahlian yang JIPTEK, Vol. VI No.1, Januari 2013 diselenggarakan agar relevan dengan permintaan dan tuntutan dunia usaha dan dunia industri (DU/DI). Salah satu langkah yang telah ditempuh oleh Direktorat Pembinaan SMK sebagai unit kerja di Kementerian Pendidikan Nasioanal yang bertanggung jawab terhadap keberadaan SMK adalah dengan menerbitkan Spektrum Keahlian SMK. Pengembangan SMK sebagai sebagai pranata utama peningkatan SDM berkualitas menjadi sangat penting, terutama berkaitan dengan dua hal yang harus berjalan seiring dan saling melengkapi, yaitu: (1) kebijakan tentang otonomi daerah dan perimbangan keuangan antara pusat dan daerah sangat memerlukan dukungan kemampuan teknis produksi yang berkualitas dan kemampuan manajerial yang handal agar dapat menghidupkan kembali roda perekonomian nasional, dan (2) tuntutan dan permasalahan era global khususnya dibidang industrialisasi dan teknologi informasi menjadi semakin ketat dan tajam, akan membawa perubahan yang sangat cepat dalam bidang ilmu pengetahuan dan teknologi. Kondisi ini di satu sisi membuka peluang mempercepat laju pembangunan, tetapi di sisi lain membawa tantangan terhadap peningkatan kualitas sumberdaya manusia, (Tim YPPTI, 2010)

Spektrum keahlian di SMK telah ditetapkan berdasarkan keputusan Dirjen Mandikdasmen Nomor 251/C/MN/2008 tanggal 27 Agustus 2008 yang diberlakukan pada awal tahun pelajaran 2008/2009 mulai kelas X. 
Sedangkan untuk kelas XI, XII, dan XIII tetap mengacu pada Surat Dirjen Mandikdasmen Nomor: 925/C.C5./KP/07tanggal 28 Februari 2007 tentang Penyesuaian Program Keahlian berdasarkan Kurikulum SMK Edisi 1999 dan 2004. Dalam keputusan tersebut program pendidikan pada SMK dikelompokkan ke dalam 6 bidang studi keahlian, yaitu kelompok atau rumpun keahlian pada SMK yang terdiri atas:

1. Teknologi dan Rekayasa;

2. Teknologi Informasi dan Komunikasi;

3. Kesehatan;

4. Seni, Kerajinan, dan Pariwisata;

5. Agribisnis dan Agroteknologi; dan

6. Bisnis dan Manajemen.

Dari 6 kelompok bidang studi keahlian, dibagi kembali ke dalam 40 program studi keahlian, yaitu jurusan dalam suatu Bidang Studi Keahlian yang pada spektrum sebelumnya disebut Bidang Keahlian. Dari 40 program studi keahlian dibagi kembali menjadi 121 Kompetensi Keahlian, yaitu spesialisasi dalam suatu Program Studi Keahlian yang pada pada spektrum sebelumnya disebut Program Keahlian. Nama-nama program pendidikan yang diselenggarakan di SMK mulai tahun pelajaran 2008/2009 disesuaikan dengan spektrum keahlian pendidikan menengah kejuruan yang baru. Selain menata kompetensi keahlian, Kementerian pendidikan Nasional juga melakukan perubahan rasio antara SMA dengan SMK menjadi 30 SMA : 70 SMK. Sejalan dengan keinginan pemerintah untuk meningkatkan jumlah SMK sehingga dicapai rasio SMK : SMA 70\% : 30\%, jumlah SMK akan terus bertambah. Hingga tahun 2008 telah dikembangkan sebanyak 100 SMA dan 341 SMK berbasis keunggulan lokal. Rasio jumlah siswa SMK:SMA dari tahun ke tahun juga terus meningkat dari 30:70 pada tahun 2004 menjadi 49:51 menurut perhitungan sementara pada akhir bulan September 2009, (Kemdiknas, 2010: 23).

Penambahan SMK ini dapat dilakukan dengan cara membuat UPT SMK baru (sekolah baru) atau dengan mengubah SMA yang tidak berkembang menjadi SMK, sehingga bermunculan SMK baru baik negeri maupun swasta dengan berbagai jenis dan program pendidikan, mulai dari program teknologi, bisnis, pariwisata dan perhotelan, pertanian, perikanan, komputer, tata boga/busana, dan lain sebagainya, (Wasimudin Surya, 2008: 3). Upaya pengembangan SMK hingga mencapai $70 \%$ dibandingkan dengan SMA, tentunya akan membutuhkan sumber daya manusia yang kompeten dibidangnya, sehingga pengelolaan
SMK akan mencapai efisien dan efektivitas yang tinggi.

Adanya penataan kompetensi keahlian dengan terbitnya spektrum keahlian dan pengembangan rasio antara SMA : SMK adalah 30 SMA : 70 SMK tersebut membawa konsekuensi pada pemenuhan tenaga guru produktif di SMK. Perubahan komposisi tersebut diperkirakan akan berimplikasi pada meningkatnya permintaan guru-guru produktif yang akan mengajar di SMK yang saat ini masih dalam kategori terbatas, (www.pppgkes.com). Disamping itu, juga dibutuhkan peningkatan kualitas dari guru-guru yang sudah ada.

Ketersediaan guru SMK selama ini didapatkan dari LPTK Kejuruan. Namun, LPTK Kejuruan yang ada di Indonesia hanya dapat memasok sebagian saja dari permintaan guru bila didasarkan pada spektrum keahlian di SMK. LPTK ternyata belum dapat untuk memenuhi permintaan guru produktif SMK dan belum dapat mengikuti perubahan yang sangat cepat dalam perkembangan ilmu pengetahuan yang sangat berdiferensiasi, (Tilaar, 2004: 42).

Pada sisi lain, seiring dengan diberlakukannya desentralisasi pendidikan pada era otonomi daerah, pemenuhan tenaga guru pada semua jenjang pendidikan menjadi keweanangan daerah, dalam hal ini adalah pemerintah kota/kabupaten, (PP. Nomor 38 Tahun 2007). Formasi untuk permintaan tenaga guru kelompok produktif menjadi hal yang belum tergarap dengan baik, karena memang penyediaan tenaga guru kelompok produktif yang sesuai dengan persyaratan tidak tersedia dan belum dapat disediakan oleh LPTK. Ironisnya, kenyataan di lapangan menunjukkan bahwa keberadaan tenaga berkualifikasi sarjana untuk program studi keahlian di SMK yang belum dapat disediakan oleh LPTK telah dihasilkan oleh perguruan tinggi non LPTK. Namun, tata aturan dan kewenangan pengangkatan tenaga guru justru menjadi kendala dalam penyediaan tenaga guru produktif, yaitu:

1. Tenaga sarjana non LPTK tidak mempunyai akta mengajar, sementara program akta sudah tidak diberlakukan lagi

2. Kewenangan mengangkat tenaga guru pada era otonami daerah menjadi hak pemerintah kota atau kabupaten

Upaya untuk pemenuhan tenaga guru produktif sudah dilakukan oleh Kementerian Pendidikan melalui Direktorat Pembinaan SMK berupa:

1. Pemenuhan permintaan guru yang efektif dalam jangka pendek adalah meminta para ahli di industri mengajar di SMK, 
2. Menggandeng perguruan tinggi yang relevan untuk mengirim mahasiswa tingkat akhir mengajar di SMK melalui program pendampingan SMK

3. Bekerja sama dengan TNI dalam program TNI Manunggal Pendidikan sehingga para prajurit terlatih juga dapat mengajar di SMK,

4. Menerapkan kebijakan double shift atau mengajar dua kali dalam sehari untuk kelas pagi dan sore bagi guru yang ada,

5. Mendorong alih kompetensi mengajar guru adaptif menjadi guru kejuruan,

6. Melakukan redistribusi guru kejuruan dari kota besar ke daerah sehingga permintaan guru produktif itu teratasi, (Pra Survey di DITPSMK bulan Agustus-Sptember 2011).

Upaya yang sudah dilakukan

Kementerian Pendidikan Nasional melalui DITPSMK merupakan usaha jangka pendek dalam memenuhi permintaan guru produktif di SMK berdasarkan spektrum keahlian SMK dan penyediaan tenaga guru dalam perspektif desentralisasi pendidikan pada era otonomi daerah. Namun upaya yang telah dilakukan tidak dapat terus menerus dilaksanakan dalam jangka panjang, karena diperlukan suatu kebijakan untuk pemenuhan tenaga guru produktif di SMK. . Untuk itu, perlu dilakukan penyelarasan antara permintaan dengan penyediaan guru produktif berdasarkan spektrum keahlian di SMK dalam perspektif desentralisasi pendidikan.

\section{HASIL DAN PEMBAHASAN Permintaan Guru}

Pendidikan merupakan suatu organisasi yang tidak terlepas dari tugas perencanaan, baik perencanaan sarana prasarana maupun perencanaan kebijakan lainnya. Demikian pula dengan perencanaan permintaan pendidikan, seperti permintaan guru, permintaan sarana penunjang dan permintaan lainnya dari sisi kualitas maupun kuantitas untuk mencapai tujuan pendidikan. Mulyasa (2002: 42-43) menguraikan; Manajamen tenaga kependidikan (guru dan personil) mencakup; (1) perencanaan pegawai, (2) pengadaan pegawai, (3) pembinaan dan pengemabangan pegawai, (4) promosi dan mutasi, (5) pemberhentian pegawai, (6) kompensasi, (7) penilaian pegawai. Semua itu perlu dilakukan dengan baik dan benar agar apa yang diharapkan tercapai, yakni tersedianya tenaga kependidikan yang diperlukan dengan kualifikasi dan kemampuan yang sesuai serta dapat melaksanakan pekerjaan dengan baik dan berkualitas.

Dalam hal permintaan guru diperlukan analisis permintaan yang mutlak harus dilakukan, karena mengelola pendidikan berarti mengelola organisasi yang di dalamnya terdiri atas manusia sebagi tenaga kerja dan sebagai peserta program pendidikan yang mengemban visi dan misi pendidikan untuk mencapai tujuan pendidikan. Lembaga pendidikan adalah suatu instansi yang tidak lepas dari pengaruh alami, seperti pension, meninggal dunia, dan dinamika kehidupan lainnya, sehingga tugas menganalisis permintaan guru menjadi hal yang sangat penting. Wardiman Djojonegoro dalam Makmun (2000: 27) menyatakan;

Faktor kekaryaan atau ketenagakerjaan merupakan unsure lingkungan yang determinan pengaruhnya tehadap citra system pendidikan. Dengan masih tingginya proporsi lebih kurang 30\% penduduk yang termasuk kategori sebagai setengah penganggur, menandakan suatu kenyataan masih cukup lebarnya jurang antara permintaan dengan penyediaan tenaga kerja. Hal ini juga terlihat dalam dunia pendidikan khususnya permintaan guru dengan pengadaan guru.

Amanah dari Kemendiknas tentang pengembangan Sekolah Menengah Kejuruan menegaskan bahwa penyelenggaraan Sekolah Menengah Kejuruan ke depan akan diperbanyak dibandingkan Sekolah Menengah Umum yakni dengan membalik komposisi 30:70 menjadi 70:30, yaitu 70\% untuk Sekolah Menengah Kejuruan dan 30\% untuk Sekolah Menengah Umum. Perubahan komposisi tersebut diperkirakan akan berimplikasi pada meningkatnya permintaan guru-guru produktif yang akan mengajar di SMK yang saat ini masih dalam kategori terbatas.

Direktur Pembinaan Sekolah Menengah Kejuruan Ditjen Mandikdasmen Kemendiknas, mengatakan agar lulusan langsung dapat tersalur ke dunia kerja, Kemendiknas berupaya memenuhi permintaan guru produktif di SMK sebesar 32.400 orang pada tahun 2010. Permintaan guru mata pelajaran produktif di SMK makin besar seiring dengan perkembangan SMK. Guru produktif di bidang pertanian, busana, elektronika, boga, komputer dibutuhkan seiring dengan semakin banyaknya SMK baik yang diselenggarakan oleh swasta maupun pemerintah. Saat ini jumlah guru SMK di 
Indonesia mencapai 99.266 orang. Seiring dengan permintaan guru SMK, maka lembaga pendidik tenaga kependidikan harus menyelenggarakan pendidikan profesi, (http://bataviase.co.id/node/357958). Sementara itu, berdasarkan perhitungan prakiraan untuk menghitung jumlah permintaan guru SMK, jumlah guru SMK yang dibutuhkan sampai tahun 2014/2015 diprediksi mencapai 36.884 untuk propinsi Jawa Tengah, dan 499.325 untuk seluruh Indonesia, (Wasimuddin Surya, 1998: 6).

Permintaan guru untuk mata pelajaran produktif ternyata memang masih belum dapat dipenuhi oleh LPTK. Untuk tahun 2010 saja jumlah guru yang dibutuhkan mencapai 32.400 orang. Jumlah tersebut sangat besar dan menjadi semakin sulit dipenuhi karena guru produktif yang dibutuhkan sebagian besar belum diselenggarakan oleh LPTK. Permintaan akan guru produktif betul-betul dirasakan sebagai suatu kendala yang sulit dipecahkan di daerah.

Permintaan guru mata pelajaran produktif di SMK saat ini dirasakan sulit dipenuhi. Hal tersebut dapat dilihat dari pernyataan Dardiansyah sebagai Kepala Bidang Pendidikan Menengah di Kotawaringin Barat, "Saat ini sudah banyak sekolah menengah kejuruan (SMK), tapi untuk mencari guru-guru produktif yang sulit. Padahal, dulu menurut janji Direktur Pendidikan SMK, guru produktif SMK itu harus dari politeknik, ternyata kelemahannya lulusan politeknik tidak memiliki kompetensi pendidikan pengajar atau sertifikat pengajar. Aturan kepegawaian untuk merekrut guru harus dari Sarjana Pendidikan. Yang dulu-dulu diterima karena mereka memiliki akta mengajar dari perguruan tinggi, sekarang sudah tidak ada lagi, (http//

media.hariantabengan.com/index/detailiptekberit aphoto/id/ 14325).

Untuk memenuhi permintaan guru produktif ternyata pihak Kemendiknas melalui Direktorat Pembinaan SMK juga mengalami kesulitan. Pada satu sisi, LPTK tidak dapat memnuhi tuntutan permintaan guru produktif di SMtK, pada sisi lain, lulusan non LPTK tidak serta merta dapat diangkat sebagai tenaga guru karena beberapa aturan dan ketentuan serta persyaratan sebagai tenaga guru produktif tidak dapat dipenuhi.

Zamroni dalam Suyanto dan Abbas (2001: 130) menyatakan; Pekerjaan guru tergolong ke dalam soft profession yang untuk melaksanakan pekerjaan tersebut memerlukan sentuhan seni (art) dan perasaan (sense). Penyiapan SDM untuk menjadi seorang soft profession bukan lulusan standar tertentu, tetapi dengan kemampuan minimal tertentu, selanjutnya pengalaman, pendidikan dan pelatihan yang berkelanjutanlah yang akan memperkokoh posisi profesionalnya.

Dari pernyataan Zamroni tersebut, sebenarnya tenaga guru produktif di SMK tidaklah mutlak harus dipenuhi oleh lulusan LPTK, karena memang untuk beberapa bidang keahlian yang ada di SMK belum diselenggarakan di LPTK. Jadi lulusan non LPTK dengan terlebih dahulu memenuhi segala aturan, persayaratan atau aturan dan persyaratan tersebut yang disesuaikan dengan kondisi lapangan seharusnya dapat mengisi permintaan tenaga guru produktif di SMK.

Berdasarkan roadmap dari Direktorat Pembinaan SMK, kondisi jumlah guru total (normatif, adaptif, dan produktif) pada tahun 2010 adalah 135.930 orang, dan target sampai tahun 2014 jumlah guru SMK mencapai 218.685 orang (DitPSMK, 2010). Suatu jumlah yang cukup besar bagi pemenuhan permintaan tenaga guru. Permintaan yang cukup besar tersebut tentunya memerlukan upaya untuk memenuhinya agar target yang telah dicanagkan dapat tercapai. Khusus untuk kondisi jumlah guru produktif pada tahun 2010 , total jumlah guru produktif yang ada sejumlah 91.266 orang. Jumlah guru produktif yang paling sedikit adalah untuk Program Studi Keahlian Kesehatan sejumlah 2.630 orang, disusul oleh Program Studi Keahlian sejumlah 5.418 orang (DitPSMK, 2010).

Berkenaan dengan permintaan guru, maka dalam renstra Kementerian Pendidikan Nasional Tahun 2010-2014 (Kemendiknas, 2010), ditegaskan bahwa tenaga guru harus ditingkatkan kualifikasi dan disertifikasi. Undang-Undang RI No. 14/2005 tentang Guru dan Dosen menempatkan guru dan dosen sebagai profesi. Guru harus memenuhi kualifikasi pendidikan minimal S-1/D-4 dan bersertifikat pendidik. Selain itu, langkah ini dilakukan untuk memastikan regenerasi guru yang berkompeten mengingat dalam kurun waktu lima tahun ke depan diperkirakan sekitar 700 ribu guru akan pensiun. Untuk mencapai target tersebut, pada tahun 2010-2014 Kemendiknas akan mempertahankan kebijakan-kebijakan peningkatan kualifikasi dan kompetensi guru yang antara lain adalah sebagai berikut.

1) Pengembangan sistem rekrutmen guru dengan pemberian beasiswa ikatan dinas pandu bakat;

2) Peningkatan sistem rekrutmen guru berkualifikasi S1/D4 yang berkompeten; 
3) Pemberian beasiswa untuk meningkatkan kualifikasi guru menjadi S-1/D-4 dan peningkatan kualifikasi dosen menjadi S2/S-3;

4) Penertiban penyelenggaraan sertifikasi pendidik sesuai dengan peraturan perundangan;

5) Peningkatan peran perguruan tinggi dalam pembinaan profesionalisme guru berkelanjutan melalui kegiatan KKG/MGMP.

\section{Kompetensi Guru}

Dalam sistem pendidikan nasional kita, eksistensi guru sangat penting, guru merupakan jabatan atau profesi yang memerlukan keahlian khusus sebagai guru. Menurut UU No. 14 tahun 2005 tentang Guru dan Dosen, guru adalah pendidik profesional dengan tugas utama mendidik, mengajar, membimbing, mengarahkan, melatih, menilai, dan mengevaluasi peserta didik pada pendidikan anak usia dini di jalur pendidikan formal, pendidikan dasar, dan pendidikan menengah (Pasal 1 ayat 1). Profesional adalah pekerjaan atau kegiatan yang dilakukan oleh seseorang dan menjadi sumber penghasilan kehidupan yang memerlukan keahlian, kemahiran, atau kecakapan yang memenuhi standar mutu atau norma tertentu serta memerlukan pendidikan profesi (Pasal 1 ayat 2).

Sebagai seorang pendidik profesional, maka seorang guru dituntut untuk memiliki kualifikasi pendidikan khusus sehingga guru memiliki kemampuan untuk menjalankan profesinya tersebut sehingga akan mencerminkan guru yang profesional. Guru yang profesional akan tercermin dalam pelaksanaan pengabdian tugas-tugas yang ditandai dengan keahlian baik dalam materi maupun metode. Guru yang professional diyakini mampu memotivasi siswa untuk mengoptimalkan potensinya dalam kerangka pencapaian standar pendidikan yang ditetapkan.

Berdasarkan hal tersebut dapat dikatakakan bahwa guru profesional pada intinya adalah guru yang memiliki kompetensi yang dipersyaratkan. Oleh karena itu jika membicarakan aspek kemampuan profesional guru berarti mengkaji kompetensi yang harus dimiliki seorang guru. Perbedaan pokok antara profesi guru dengan profesi lainnya adalah terletak pada tugas dan tanggung jawabnya. Tugas dan tanggung jawab tersebut erat kaitannya dengan kemampuan yang disyaratkan untuk memangku profesi tersebut. Kemampuan dasar tersebut tidak lain adalah kompetensi guru, Uno (2007: 79).

Kompetensi adalah seperangkat pengetahuan, keterampilan dan perilaku yang harus dimiliki, dihayati dan dikuasai guru atau dosen dalam melaksanakan tugas keprofesionalan ( Pasal 1 ayat 10 UU No 14 tahun 2005 tentang Guru dan dosen). Menurut Majid (2005: 5) kompetensi adalah seperangkat tindakan inteligen penuh tanggung jawab yang harus dimiliki seseorang sebagai syarat untuk dianggap mampu melaksankan tugas-tugas dalam pekerjaan tertentu. Sikap inteligen harus ditunjukkan sebagai kemahiran, ketepatan dan keberhasilan bertindak. Sifat tanggungjawab harus ditunjukkan sebagai kebenaran tindakan baik dipandang dari sudut ilmu pengetahuan, teknologi maupun etika. Usman (2005) dalam Kunandar (2007:51) menyatakan kompetensi adalah suatu hal yang menggambarkan kualifikasi dan kemampuan seseorang, baik yang kualitatif maupun yang kuantitatif. Kompetensi juga dapat diartikan sebagai pengetahuan, keterampilan dan nilai-nilai dasar yang direfleksikan dalam kebiasaan berfikir dan bertindak. Dengan demikian kompetensi yang dimiliki oleh setiap guru akan menunjukkan kualitas guru yang sebenarnya (Direktorat Tenaga Kependidikan Depdiknas, 2003). Kunandar (2007: 55), menyatakan bahwa kompetensi guru adalah seperangkat penguasaaan keammpuan yang harus ada dalam diri guru agar dapat mewujudkan kinerjanya secara tepat dan efektif.

Dalam Undang-Undang Guru dan Dosen No 14 tahun 2005 dinyatakan "Kompetensi guru meliputi kompetensi pedagogik, kompetensi kepribadian, kompetensi sosial dan kompetensi profesional yang diperoleh melalui pendidikan profesi”. Direktorat Ketenagaan Dirjen Dikti dan Direktorat Profesi Pendidik dalam Kunandar (2007: 77) mengklasifikasikan keempat kompetensi tersebut atas sub kompetensi seperti berikut.

1) Kompetensi pedagogik adalah kemampuan mengelola pembelajaran peserta didik. Kompetensi ini terdiri dari Sub Kompetensi ; (a) Memahami peserta didik secara mendalam; (b) Merancang pembelajaran, termasuk memahami landasan pendidikan untuk kepentingan pembelajaran; (c) Melaksanakan pembelajaran;

Merancang dan melaksankan evaluasi pembelajaran; (e) Mengembangkan peserta didik untuk mengaktualisasikan berbagai potensinya. 
2) Kompetensi kepribadian adalah kemampuan pribadi yang mantap, stabil, dewasa, arif, berwibawa, berakhlak mulia yang menjadi teladan bagi peserta didik.Kompetensi ini terdiri dari Sub Kompetensi; (a) kepribadian yang mantap dan stabil; (b) Kperibadian yang dewasa; (c) Kepribadian yang arif; (d) Kepribadian yang berwibawa; (e) Berakhlak mulia dan dapat menjadi teladan.

3) Kompetensi sosial adalah kemampuan guru untuk berkomunikasi dan berinteraksi secara efektif dan efisien dengan peserta didik, sesama guru, orang tua/ wali peserta didik, dan masyarakat sekitar. Kompetensi ini teridri dari Sub Kompetensi; (a) Mampu berkomunikasi dan bergaul secara efektif dengan peserta didik; (b) Mampu berkomunikasi dan bergaul secara efektif dengan sesama pendidik dan tenaga kependidikan; (c) Mampu berkomunikasi dan bergaul secara efektif dengan orang tua atau wali peserta didik an masyarakat sekitar.

4) Kompetensi professional adalah kemampuan menguasai materi pembelajaran secara luas dan mendalam. Kompetensi ini tersdiri dari Sub Kompetensi;

(a) Menguasai substansi keilmuan yang terkait dengan bidang studi; (b) Menguasai struktur dan metode keilmuan.

\section{Keberadaan Guru}

Ketersediaan guru merupakan syarat penting dalam penyelenggaraan pendidikan di SMK. Begitu pentingnya peranan seorang guru dalam penyelenggaraan pendidikan di SMK, sehingga Charles Prosser menempatkan 3 teori pokok pendidikan kejuruan yang terkait dengan keberadaan guru dari 16 teori pendidikan kejuruan (dalil prosser), yaitu:

Teori ke-7: Pendidikan kejuruan akan efektif jika gurunya telah mempunyai pengalaman yang sukses dalam penerapan keterampilan dan pengetahuan pada operasi dan proses kerja yang akan dilakukan; Teori ke-11: Sumber yang dapat dipercaya untuk mengetahui isi pelatihan pada suatu okupasi tertentu adalah dari pengalaman para ahli pada okupasi tersebut; Teori ke-14: Pendidikan kejuruan akan efisien jika metode pengajaran yang digunakan dan hubungan pribadi dengan peserta didik mempertimbangkan sifat-sifat peserta didik tersebut, (Prosser dalam Djojonegoro, 1998: 38-39)
Keberadaan guru dalam dunia pendidikan memegang peranan yang sentral, meskipun dengan perkembangan inovasi pembelajaran saat ini. Peranan guru sebagai fasiltator tetap memegang peranan kunci dalam kegiatan belajar mengajar di kelas. Untuk itu, guru SMK harus mempunyai kompetensi pengetahuan dan keterampilan dalam bidangnya, menguasai materi pelajaran, dan mengauasi metode pengajaran yang memperhatikan sifat peserta didik.

Berkaitan dengan peranan guru dalam upaya pengembangan SMK tentunya harus direncanakan secara komprehensif sehingga pengembangan tersebut tidak hanya menyangkut kuantitas tetapi juga harus menyangkut kualitas, produktifitas, dan relevansi agar tujuan sebenarnya dari pengembangan tersebut dapat diwujudkan (Yadi Mulyadi, 2010: 864-865). Upaya pengembangan SMK hingga mencapai 70 $\%$ dibandingkan dengan SMU, tentunya akan membutuhkan sumber daya manusia (SDM) yang kompeten dibidangnya, sehingga pengelolaan SMK akan mencapai efisiensi dan efektivitas yang tinggi. Dalam tataran mikro, diantara sumber daya manusia yang sangat dibutuhkan pada kegiatan pembelajaran di SMK adalah guru. Secara sistemik, output berkaitan erat dengan proses, dan proses terkait dengan input, sehingga kualitas proses akan berimplikasi langsung terhadap kualitas hasil. Berdasarkan hal tersebut, upaya peningkatan mutu lulusan SMK berkaitan erat dengan peningkatan mutu proses pembelajaran, dengan guru merupakan salah satu instrumental input dominannya. Dengan demikian peningkatan guru baik secara kualitas dan kuantitas merupakan keharusan untuk memecahkan masalah kualitas pendidikan khususnya di SMK yang terjadi saat ini.

\section{Penyediaan Tenaga Guru Produktif}

Penyediaan tenaga guru dalam suatu instansi pendidikan termasuk di dalamnaya adalah guru produktif untuk Sekolah Menengah Kejuruan (SMK) merupakan hal mutlak yang harus dilaksanakan oleh pihak yang berwenang dalam mengambil kebijakan untuk penyediaan tenaga guru. Tilaar (2001: 112) menyatakan bahwa; "Pengadaan dan penempatan guru haruslah merupakan satu paket, artinya tenaga guru untuk daerah dipersiapkan dalam satu program secara cermat, baik dalam jumlah maupun kualifikasi fisik dan psikis dalam suatu program khusus".

Penyediaan guru berkaitan dengan tugas guru sebagai fasilitator dalam proses belajar mengajar yang langsung berhadapan dengan 
siswa, sehingga rasio antara guru dengan murid selalu harus seimbang demi terlaksananya proses belajar mengajar yang bermutu. Zamroni dalam Suyanto \& Abbas (2001: 130) menyatakan;

Pekerjaan guru tergolong ke dalam soft profession yang untuk melaksanakan pekerjaan tersebut memerlukan sentuhan seni (art) dan perasaan (sense). Penyiapan SDM untuk menjadi soft profession bukan lulusan standar tertentu, tetapi dengan kemampuan minimal tertentu, selanjutnya pengalaman, pendidikan dan pelatihan yang berkelanjutanlah yang akan memperkokoh posisi profesionalnya.

Penyediaan tenaga guru SMK di Indonesia secara mayoritas saat ini dihasilkan dari LPTK Negeri yang menyelenggaran program pendidikan untuk guru kejuruan dan beberapa LPTK swasta yang sejenis. LPTK Negeri yang menyelenggarakan program pendidikan untuk guru kejuruan sejumlah 14 LPTK, yaitu FT Universitas Negeri Medan, FT Universitas Negeri Padang, FT Universitas Negeri Jakarta, FPTK Universitas Pendidikan Indonesia Bandung, FT Universitas Negeri Yogyakarta, FT Universitas Negeri Semarang, JPTK FKIP Universitas Sebelas Maret, FT Universitas Negeri Surabaya, FT Universitas Negeri Malang, FPTK Universitas Pendidikan Ganesha Singaraja, FT Universitas Negeri Makassar, FT Universitas Negeri Manado, FT Universitas Negeri Gorontalo, dan JPTK FKIP Universitas Nusa Cendana Kupang.

Program Studi yang diselenggarakan oleh LPTK tersebut rata-rata adalah BELMO (Bangunan, Elektronilka, Listrik, Mesin dan Otomotif) ditambah PKK (Boga, Busana, dan Kecantikan) dan beberapa LPTK saat ini sudah membuka program studi informatika.

Proses penyediaan guru profesional masih banyak kelemahannya dan perlu adanya pembenahan yang berlanjut. Tidak hanya pada proses rekruitment calon guru saja, tapi pembenahannya harus berjalan menyeluruh, sampai pada pengawasan atau supervisi kinerja guru.Pemerintah menyadari adanya kesulitan dalam penyediaan guru profesional dalam jumlah yang mencukupi. Ketidakcermatan dalam proses rekruitmen calon guru, proses penyiapan calon guru dijenjang pendidikan prajabatan, hingga proses rekruitmen, penempatan, pelatihan dalam jabatan, dan proses supervisi kinerja guru, merupakan siklus yang perlu mendapat perhatian untuk benahi,(http://arsipkorankita.blogspot.com/ profesional.html).

Menurut H.A.R. Tilaar, proses penyediaan tenaga guru dalam menghadapi abad ke-21, tidak dapat lagi mengandalkan pada lembaga-lembaga tinggi tradisonal seperti LPTK. Ilmu pengetahuan yang berkembang sangat pesat dan mengalami perubahan-perubahan paradigma menuntut juga perubahan paradigm dalam pendidikan untuk penyediaan tenaga guru. LPTK tidak dapat mengikuti perubahan yang sangat cepat dalam ilmu pengetahuan dan teknologi yang direspon sangat cepat oleh SMK. Oleh karena itu, sosok guru yang harus tersedia adalah guru yang ilmuwan sekaligus pendidik, (2004: 42).

Dalam Rencana Kerja dan Anggaran Kemdiknas Tahun 2012, keberadaan dari tenaga guru yang kompeten menjadi salah satu prioritas di dalam percepatan pembangunan pendidikan. Percepatan dalam bidang penyediaan dan peningkatan mutu pendidik dan tenaga kependidikan meliputi kualifikasi, sertifikasi, distribusi, penyediaan, kesejahteraan, pelatihan, dan peningkatan LPTK, (Kemdiknas, 2011). Secara lebih jelas, kedudukan percepatan pembangunan pendidikan yang berkaitan dengan penyediaan guru dapat dilihat pada gambar berikut. 


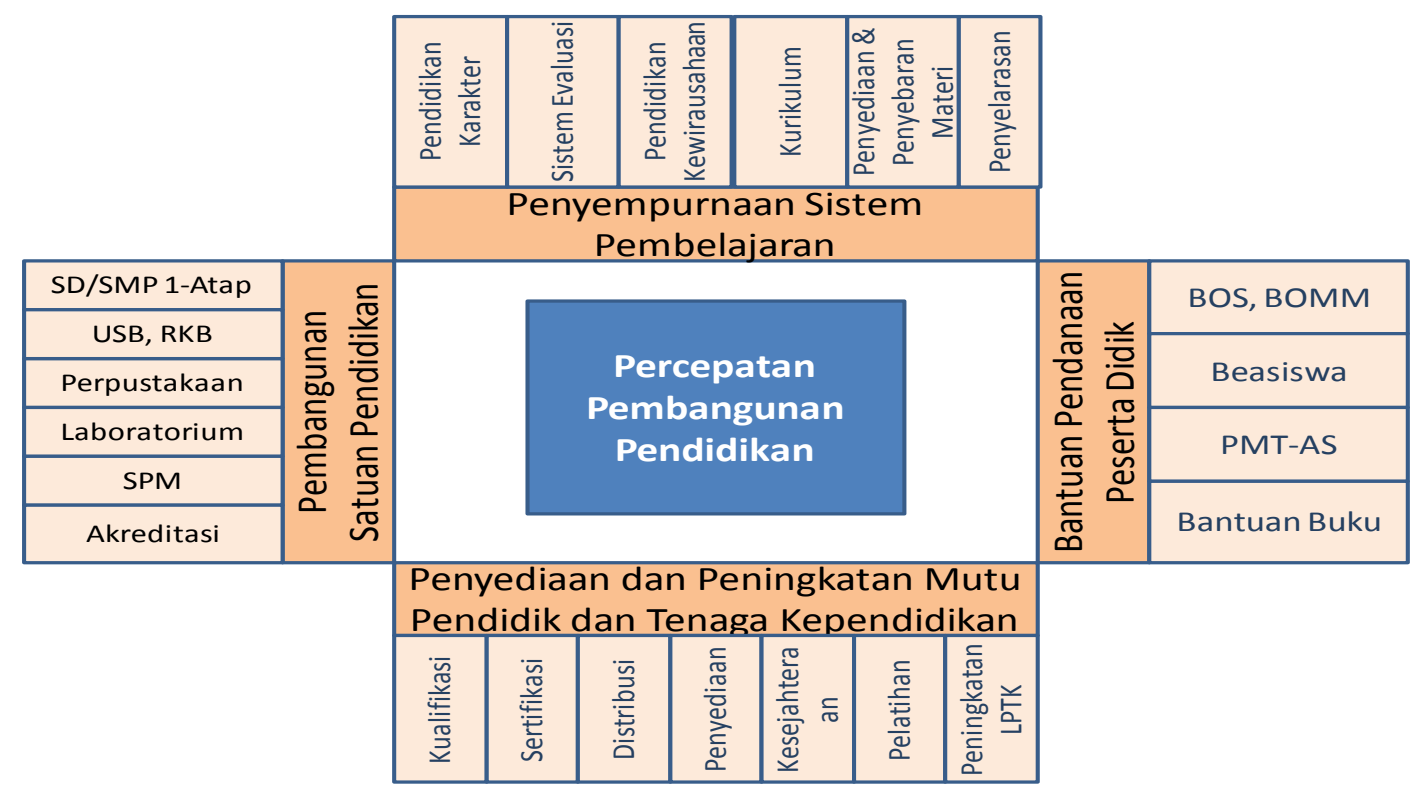

Gambar 1. Percepatan Pembangunan Pendidikan Sumber: Kemdiknas, 2011

Penyediaan tenaga guru merupakan faktor yang sangat dominan dalam menciptakan pendidikan yang bermutu. Banyak hambatan sebagai tantangan yang ditemui dalam proses penyediaan tenaga guru yang kompeten. Dalam Renstra Kemdiknas 2010-2014 (Kemdiknas, 2010), telah diidentifikasi berbagai tantangan yang dihadapi dalam melaksanakan pembangunan pendidikan tahun 2010-2014. Diantara tantangan tersebut adalah mengembangkan kebijakan pemberdayaan tenaga pendidik dan kependidikan dengan memperhatikan profesionalisme dan peningkatan koordinasi yang efektif dengan kementerian/lembaga lain dan pemerintah daerah;

Guru sebagai input dominan yang berfungsi sebagai agen perubahan pembelajaran yang profesional, sesuai dengan Undang-Undang Guru dan Dosen dan juga Standar Nasional Pendidikan setidaknya harus memiliki tiga pilar yaitu (1) kualifikasi, (2) kompetensi agen pembelajaran, sehat jasmani dan rohani, memiliki kemampuan untuk mewujudkan tujuan pendidikan nasional serta memiliki (3) sertifikat. Dengan demikian guru harus memiliki kualifikasi yang dipersyaratkan, kompetensi yang terstandar, dan mampu mendukung dan menyelenggarakan pendidikan secara profesional sehingga akan menghasilkan mutu pendidikan yang baik.

\section{Spektrum Keahlian SMK}

Dalam rangka mendukung kebijakan pengembangan SMK dengan rasio siswa sekitar $70 \%$, akan banyak dibutuhkan guru SMK. Namun penambahan guru tersebut harus memperhatikan beberapa aspek sehingga kebijakan ini tepat sasaran. Beberapa aspek yang perlu diperhatikan antara lain: bidang dan program keahlian apa saja yang sebenarnya dibutuhkan, besarnya rasio siswa:guru, sebaran atau proporsi guru menurut bidang/program keahlian, serta bagaimana relevansinya dengan bidang dan program keahlian yang dibutuhkan dunia usaha dan industri (DUDI) di kabupaten/kota di Indonesia.

Selain itu, sesuai dengan UU No.14/2005 tentang Guru dan Dosen dan PP No. 19/2005 tentang Standar Nasional Pendidikan, guru harus mempunyai kualifikasi dan kompetensi yang sesuai dengan yang dibutuhkan SMK. Oleh karena itu penambahan jumlah guru SMK perlu memperhatikan bidang dan program keahlian yang dibuka di tiap kabupaten/kota di Indonesia.

Didalam perkembangan SMK banyak program keahlian yang dikembangkan oleh masing-masing SMK penamaannya tidak mengikuti ketentuan yang diberlakukan. Penamaan yang tidak tidak berdasarkan ketentuan yang berlaku akan menyulitkan dalam pengelolaan dan penyediaan tenaga pendidik serta ketidakjelasan akan pengakuan masyarakat pengguna. Oleh karena itu, Direktur Jenderal manajemen Pendidikan Dasar dan Menengah 
pada tanggal 22 Agustus 2008 menerbitkan surat keputusan nomor 251/C/KEP/MN/2008 tentang spektrum keahlian pendidikan menengah kejuruan. Sebagai pertimbangan dikeluarkannya SK tersebut adalah bahwa spektrum keahlian yang telah diberlakukan sudah tidak sesuai dengan tuntutan kurikulum tingakat satuan pendidikan, perkembangan ilmu pengetahuan, teknologi, dan tututan dunia kerja. Spektrum keahlian pada dasarnya menggambarkan alur atau pola pengelompokkan program keahlian yang disusun berdasarkan kesetaraan atau kaitan dengan kompetensi kerja yang diperlukan oleh dunia kerja terkait.

Berdasarkan SK tersebut, ada 6 bidang keahlian yang dikembangkan di Sekolah Menengah Kejuruan, dengan total program studi keahlian sebanyak 40, dan kompetensi keahlian sebanyak 121. Tabel berikut menunjukkan jumlah program studi keahlian dan kompetensi keahlian masing-masing bidang keahlian.

Tabel 1. Spektrum Bidang Keahlian di SMK

\begin{tabular}{|c|l|c|c|}
\hline \hline No. & \multicolumn{1}{|c|}{ Bidang Keahlian } & $\begin{array}{c}\text { Program } \\
\text { Studi } \\
\text { Keahlian }\end{array}$ & $\begin{array}{c}\text { Kompetensi } \\
\text { Keahlian }\end{array}$ \\
\hline \hline 1 & Teknologi dan Rekayasa & 18 & 66 \\
\hline 2 & Teknologi Informasi dan Komunikasi & 3 & 9 \\
\hline 3 & Kesehatan & 2 & 6 \\
\hline 4 & Seni, Kerajinan, dan Pariwisata & 7 & 22 \\
\hline 5 & Agribisnis dan Agroteknologi & 7 & 14 \\
\hline 6 & Bisnis dan Manajemen & 3 & 4 \\
\hline \hline \multicolumn{2}{|c|}{ Jumlah } & $\mathbf{4 0}$ & $\mathbf{1 2 1}$ \\
\hline \hline
\end{tabular}

(Sumber: Ditjen Mandikdasmen, 2008).

Mengingat banyaknya bidang dan program keahlian di SMK, maka guru yang mengajar juga harus memiliki kualifikasi dan kompetensi yang sesuai dengan bidang atau program keahlian yang dibutuhkan SMK.

\section{DESENTRALISASI PENDIDIKAN Konsep Desentalisasi Pendidikan}

Istilah desentralisasi pendidikan mengemuka seiring dengan bergulirnya reformasi di Indonesia yang menuntut adanya reformasi total dalam segala bidang. Istilah tersebut serempak muncul dengan istilah otonomi, sentralisasi, dan desentralisasi. Otonomi dan desentralisasi merupakan istilah yang sering dicampuradukkan penggunaannya dalam konteks pembicaraan atau diskusi tentang system penyelenggaraan pemerintahan atau ketatanegaraan, padahal secara konsep diantara keduanya sangat berbeda, tetapi secara praktis dalam penyelenggaraan pemerintahan suatu Negara, antar keduanya tidak dapat dipisahkan, (Irianto, 2011: 65).

Desentralisasi pendidikan di Indonesia ditandai dengan dikeluarkannya Undang Undang No. 20 Tahun 2003 yang menggantikan Undang - Undang No. 2 Tahun 1989 tentang Sistem Pendidikan Nasional. Dalam pasal 4 ayat 6 disebutkan "Pendidikan diselenggarakan JIPTEK, Vol. VI No.1, Januari 2013 dengan memberdayakan semua komponen masyarakat melalui peran serta dalam penyelenggara dan pengendali mutu layanan pendidikan", (http://www.blogguru.web.id/2011/04/desentralisasi-pendidikanindonesia.html).

Secara konseptual, terdapat dua jenis desentralisasi pendidikan, yaitu: pertama, desentralisasi kewenangan di sektor pendidikan dalam hal kebijakan pendidikan dan aspek pendanaannya dari pemerintah pusat ke pemerintah daerah (propinsi dan distrik), dan kedua, desentralisasi pendidikan dengan fokus pada pemberian kewenangan yang lebih besar di tingkat sekolah. Konsep desentralisasi pendidikan yang pertama terutama berkaitan dengan otonomi daerah dan desentralisasi penyelenggaraan pemerintahan dari pusat ke daerah, sedangkan konsep desentralisasi pendidikan yang memfokuskan pada pemberian kewenangan yang lebih besar pada tingkat sekolah dilakukan dengan motivasi untuk meningkatkan kualitas pendidikan, (Burki, 1999: 50)

Tujuan dan orientasi dari desentralisasi pendidikan sangat bervariasi berdasarkan pengalaman desentralisasi pendidikan yang dilakukan di beberapa negara Amerika Latin, di Amerika Serikat dan Eropa. Jika yang menjadi tujuan adalah pemberian kewenangan di sektor 
pendidikan yang lebih besar kepada pemerintah daerah, maka fokus desentralisasi pendidikan yang dilakukan adalah pada pelimpahan kewenangan yang lebih besar kepada pemerintah lokal atau kepada Dewan Sekolah. Implisit ke dalam strategi desentralisi pendidikan yang seperti ini adalah target untuk mencapai efisiensi dalam penggunaan sumber daya (school resources; dana pendidikan yang berasal yang pemerintah dan masyarakat). Di lain pihak, jika yang menjadi tujuan desentralisasi pendidikan adalah peningkatan kualitas proses belajar mengajar dan kualitas dari hasil proses belajar mengajar tersebut, maka desentralisasi pendidikan lebih difokuskan pada reformasi proses belajarmengajar. Partisipasi orang tua dalam proses belajar mengajar dianggap merupakan salah satu faktor yang paling menentukan. Dalam kenyataannya, desentralisasi pendidikan yang dilakukan di banyak negara merupakan bagian dari proses reformasi pendidikan secara keseluruhan dan tidak

sekedar merupakan bagian dari proses otonomi daerah dan desentralisasi fiskal.

Desentralisasi pendidikan akan meliputi suatu proses pemberian kewenangan yang lebih luas di bidang kebijakan pendidikan dan aspek pendanaannya dari pemerintah pusat ke pemerintah lokal dan pada saat yang bersamaan kewenangan yang lebih besar juga diberikan pada tingkat sekolah, (Armida S. Alisjahbana, 2000: 2$3)$.

Adapun maksud dari perlunya desentralisasi dalam bidang pendidikan dikemukakan oleh Rondinelli dan Cheema (dalam Irianto, 2011: 81);

Dezentralization in the transfer of planning, decision making, or administrative authority from the central government to its field organizations, local administrative units, semiautonomous and parastatal organizations, local government, or non government organizations.

............................. different

forms of the decentralization can be disintingished primary by the extent to which authority to plan, decide and manage is transferred from central government to other organization and the amount of autonomy the 'decentralized organizations' achieved in carring out their tasks.
Dalam konsepnya, desentralisasi dalam bidang pendidikan merupakan upaya untuk mendelegasikan sebagian atau seluruh wewenang di bidang manajemen pendidikan yang seharusnya dilakukan oleh unit atau pejabat organisasi di tingkat pusat kepada unit atau pejabat di bawahnya atau dari pemerintah pusat pada pemerintah daerah, atau dari pemerintah kepada masyarakat. Namun tidak semua bidang pendidikan dapat didesentralisasikan, kewenangan perumusan atau pembuatan kebijaksanaan nasional mengenai pendidikan meliputi kurikulum, persyaratan pokok tentang jenjang pendidikan, persyaratan pembukaan program baru, persyaratan tentang guru di setiap jenjang pendidikan, dan kegiatan strategis lainnya masih tetap harus disentralisasikan.

\section{Kritik Terhadap Pelaksanaan Desntralisasi Pendidikan}

Kementerian Pendidikan Nasional akan melakukan kajian untuk mengembalikan semua urusan pendidikan ke pemerintah pusat. Menteri Pendidikan Nasional Mohammad Nuh menyatakan sudah membentuk tim untuk meneliti desentralisasi pendidikan yang ditangani daerah yang meliputi analisis kefektifan dan kefisienan dan dampak dari desentralisasi pendidikan kepada masyarakat, (http://diksia.com/2011/03/kemdiknas-kaji-

ulang-desentralisasi-pendidikan/). Sementara Suyanto sebagai Plt Dirjen Pendidikan Dasar mendukung langkah evaluasi dampak desentralisasi pendidikan, karena adanya unsur politik di daerah yang mencampuri urusan pendidikan,

(http://diksia.com/ 2011/03/kemdiknas-kaji-ulang-desentralisasipendidikan/). Dan menurut DPR, untuk hal-hal yang berkaitan dengan guru sudah jelas akan diambil alih oleh pusat, karena DPR menilai pemerintah daerah sudah melanggar batasnya dalam memutasi guru terutama pada masa kampanye (http://diksia.com/2011/03/kemdiknaskaji-ulang-desentralisasi-pendidikan/)

Rencana Kementerian Pendidikan Kemdiknas untuk mengembalikan kewenangan penanganan tenaga pendidik, seperti guru dan kepala sekolah ke tangan pemerintah pusat, dan tidak lagi di tangan pemerintah daerah adalah ditanggapi positif oleh banyak kalnagan terutama kalangan guru sendiri. Seperti dinyatakan oleh Gede Putra Adnyana guru SMA Buleleng (dalam http://www.psb-psma.org/content/blog/3793- 
menggugat-desentralisasi-pendidikan) langkah tersebut adalah suatu langkah cerdas. Dikatakan cerdas, karena ini merupakan langkah antisipasi terhadap tindakan egois dan otoriter dari sebagian pejabat daerah. Tidak jarang tindakan itu menghancurkan sistem pendidikan, karena pejabat daerah yang berwenang tidak memahami sitem pendidikan secara komprehensif. Oleh karena itu mengkaji ulang desentralisasi pendidikan adalah keniscayaan sehingga lebih banyak manfaat ketimbang mudaratnya.

Beberapa hal yang banyak dikritik dalam desentralisasi pendidikan menurut Gede Putra Ardana , (dalam http://www.psbpsma.org/content/blog/3793-menggugatdesentralisasi-pendidikan) adalah;

\section{- Mutasi}

Fakta di lapangan menunjukkan bahwa desentralisasi pendidikan memberikan kewenangan kepada pemerintah daerah untuk melaksanakan mutasi pendidik dan tenaga kependidikan. Tingginya frekuensi mutasi ini dipengaruhi oleh dinamika politik di daerah. Mohammad Nuh mengemukakan bahwa di antara empat komponen sekolah (kurikulum, infrastruktur, guru, dan sistem pembelajaran), tenaga pendidiklah yang paling rawan terpengaruh politik daerah (www.kompas.com, 24/6/2011). Pada desentralisasi pendidikan, banyak terjadi mutasi dengan frekuensi yang tinggi berdampak kurang baik terhadap dunia pendidikan. Karena pendidik dan tenaga kependidikan yang dimutasi harus melakukan adaptasi terhadap lingkungan yang baru. Apalagi mutasi terjadi bukan karena permohonan sendiri. Kondisi ini berdampak negatif terhadap penyelenggaraan pendidikan secara keseluruhan. Pada sisi yang lain, mutasi lintas kabupaten sangat sulit dilakukan, karena setiap kabupaten telah memiliki data kepegawaian dan anggaran setiap tahun yang tetap. Padahal, banyak pendidik dan tenaga kependidikan yang berkenan pulang kampung untuk membangun daerah kelahirannya. Pada umumnya sosok putra daerah akan memiliki fanatisme, dedikasi, komitmen dan tanggung jawab yang lebih tinggi terhadap tanah kelahirannya dibandingkan non putra daerah. Kondisi ini langsung atau tidak langsung menghambat upaya pembangunan pendidikan secara holistik. Mutasi yang dilakukan pemerintah daerah terkadang tidak proporsional dan profesional. Kondisi ini sangat dipengaruhi oleh perkembangan politik di daerah. Tidak dapat dipungkiri bahwa yang abadi dalam politik adalah kepentingan. Dalam hal ini berlaku prinsip, jika mempunyai kepentingan dan pandangan yang sama maka dia adalah kawan. Sebaliknya, jika berbeda maka dia adalah lawan. Dirjen Pendidikan Dasar, Kementerian Pendidikan Nasional, Suyanto, mengatakan bahwa politik daerah yang ikut campur dalam pendidikan sangat merugikan dunia pendidikan. Ketika urusan guru berada di tangan daerah, posisi guru sangat rentan dipindah karena kepentingan politik atau masalah pribadi (www.kompas.com, 24/6/2011). Jika pendidikan telah dikotori oleh politik, maka lambat laun namun pasti pendidikan mengalami kemunduran dan bahkan kehancuran.

\section{- Rekruitmen Tenaga Guru}

Desentralisasi pendidikan juga memberikan kewenangan kepada pemerintah daerah untuk melakukan rekrutmen pegawai dan pejabat di bidang pendidikan. Akibatnya, nuansa kolusi, korupsi, dan nepotisme (KKN) sangat kental terjadi. Karena, semakin sempit wilayah maka kekerabatan semakin dekat sehingga neoptisme tidak dapat dihindari. Pengangkatan kepala sekolah dan pejabat pendidikan strategis lainnya yang tidak dilakukan dengan profesional akan melahirkan figur tidak sesuai dengan harapan. Oleh karena itu sistem rekrutmen yang diwarnai KKN diyakini akan menghasilkan produk yang tidak berkualitas. Ketika pejabat yang berwenang mengambil kebijakan dalam bidang pendidikan tidak berkualitas dan tidak memahami pendidikan secara holistik, maka keputusan yang diambil cenderung tidak berdampak positif terhadap perkembangan dunia pendidikan.

\section{- Birokrasi}

Birokrasi administrasi kepegawaian dalam dunia pendidikan juga menjadi lebih panjang dan berbelit, akibat penerapan desentralisasi pendidikan. Mekanisme kenaikan pangkat harus melalui tahap-tahap yang lebih banyak. Kondisi ini melahirkan sistem yang tidak efektif dan efisien, karena memakan waktu, biaya, dan tenaga lebih banyak. Pengorbanan waktu, biaya, dan tenaga yang lebih banyak untuk pengurusan administrasi pendidikan dipastikan mengurangi pelayanan kepada siswa. Ide awal desentralisasi pendidikan sesungguhnya untuk efektivitas dan efisiensi birokrasi. Tetapi, ide itu jauh panggang dari api. Fakta di lapangan menunjukkan bahwa arogansi kekuasaan pemerintah daerah justru menyebabkan kontra produktif dengan ide tersebut. 


\section{- Pembiayaan}

Desentralisasi pendidikan ternyata juga berdampak negatif terhadap pembiayaan pendidikan. Terhambatnya penyaluran dana bantuan sekolah (BOS) patut diduga disebabkan adanya desentralisasi pembiayaan pendidikan. Penyaluran BOS yang harus mendapatkan persetujuan DPRD merupakan faktor penghambat utama. Mekanisme yang berbelit, mulai dari pengamprahan sampai menunggu ketok palu DPRD memakan waktu, biaya, dan tenaga yang banyak. Sementara itu, sekolah sangat mendesak memerlukan dana itu untuk penyenggaraan pendidikan. Oleh karena itu sangat relevan dan signifikan jika desentralisasi pendidikan dikaji ulang demi efektivitas dan efisiensi penyelenggaraan pendidikan dalam rangka meningkatkan kualitas sumber daya manusia.

\section{PENYELARASAN ANTARA PERMINTAAN DENGAN PENYEDIAAN TENAGA GURU KELOMPOK PRODUKTIF DI SMK}

Pada dasarnya penyelarasan merupakan upaya penyesuaian pendidikan sebagai pemasok SDM dengan dunia kerja yang memiliki permintaan dan tuntutan yang dinamis. Konsep penyelarasan mengisyaratkan adanya permintaan koordinasi yang baik antara pihak penyedia lulusan pendidikan dengan pihak yang membutuhkan tenaga lulusan. Analisis permintaan dunia kerja yang meliputi kualitas/kompetensi dan kuantitas pada lokasi dan waktu yang berbeda merupakan informasi awal yang perlu disediakan dalam proses penyelarasan. Informasi permintaan dunia kerja yang akurat dan rencana pengembangan nasional di berbagai sektor diperlukan dalam reengineering sistem pendidikan pada setiap level dan bidang dalam menyediakan SDM sesuai dengan permintaan dunia kerja, http://www.penyelarasan.kemdiknas.go.id/?panca dewa $=$ content $\&$ id $=20100508192653 \&$ title $=$ Kera ngka-Kerja-Penyelarasan).

Konsep pengembangan kerangka kerja penyelarasan pendidikan harus memperhatikan tiga komponen utama yaitu sisi permintaan, sisi pasokan dan mekanisme penyelarasan. Dalam merumuskan program penyelarasan yang bersifat komprehensif dibutuhkan gambaran kedepan dari beberapa dimensi yang relevan. Proyeksi permintaan kedepan terhadap kompetensi yang dibutuhkan dari dunia kerja dan jumlahnya pada setiap lokasi di Indonesia sangat diperlukan dan harus mengacu pada karakteristik khusus dan potensi yang dimiliki lokasi/daerah tersebut, untuk itu informasi rencana pengembangan diperlukan sebagai dasar peramalan ke depan. Pertimbangan rencana pembangunan daerah dalam program penyelarasan memberikan diharapkan dapat mengurangi terjadinya disparitas dalam hal aksesibilitas dan mampu mendayagunakan potensi yang ada di daerah.

\section{SIMPULAN}

Proses penyediaan guru produktif SMK masih banyak kelemahannya dan perlu adanya pembenahan yang berlanjut. Tidak hanya pada proses rekruitment calon guru saja, tapi pembenahannya harus berjalan menyeluruh, sampai pada pengawasan atau supervisi kinerja guru. Beberapa kesulitan kesulitan dalam penyediaan guru produktif dalam jumlah yang mencukupi, diantaranya adalah. ketidakcermatan dalam proses rekruitmen calon guru, proses penyiapan calon guru dijenjang pendidikan prajabatan, hingga proses rekruitmen, penempatan, pelatihan dalam jabatan, dan proses supervisi kinerja guru, merupakan siklus yang perlu mendapat perhatian untuk dibenahi

Pola penyelarasan yang terkait dengan permintaan dan penyediaan guru dapat dilakukan dengan memanfaatkan model kegiatan yang sudah berjalan di dunia pendidikan saat ini, yaitu melalui program kegiatan sertifikasi guru dan kerjasama antara LPTK dengan Non LPTK bersama Pemerintah Daerah. Program kegiatan tersebut masing-masing berjalan sendiri-sendiri secara terpisah. Mekanisme komunikasi dan koordinasi dalam upaya penyelarasan merupakan permintaan mutlak, oleh karena itu perlu ada mediator yang memfasilitasi penyatuan dari program kegiatan yang sudah berjalan. Setiap program yang didisain oleh masing-masing pihak perlu dijaga dan didesain untuk mengarah pada penyelarasan.

Penyelarasan antara permintaan tenaga guru mata pelajaran produktif dengan penyediaan guru dilakukan dengan menyesuaikan dan mensinergikan ketersediaan guru yang dapat dihasilkan dari LPTK dan sarjana yang dihasilkan dari non LPTK tetapi bidang ilmunya sesuai dengan permintaan SMK. Kondisi tersebut akan memerlukan kerjasama antara LPTK dengan perguruan tinggi non LPTK dan 
Kementerian Pendidikan Nasional serta pemerintah kota/kabupaten.

\section{DAFTAR PUSTAKA}

Abin Syamsudin Makmun. (2000). Analisis Posisi Pendidikan. Bandung: IKIP Bandung.

Alisjahbana, A.S. (2000). Otonomi Daerah dan Desntralisasi Pendidikan. Bandung: Unpad Bandung.

Alma, Buchari dkk. (2008). Guru Profesional: Menguasai Metode dan Terampil Mengajar. Bandung: Alfabeta.

Bogdan \& Biklen. (1990). Riset Kualitatif untuk Pendidikan, Pengantar Ke Teori dan Metode (Alih Bahasa: Munandir). Jakarta: PAU-PPAI

Burki, Shahid J., Guillermo E. Perry and William R. Dillinger. (1999). Beyond the Center:Decentralizing the State., Washington, D.C.: The World Bank.

Daryanto. (2008). Administrasi Pendidikan. Jakarta: Rineka Cipta.

Dharma, Agus. (2004). Manajemen Supervisi (Petunjuk Praktis Bagi para Supervisor). Jakarta: Raja Grafindo Persada

Ditjen Mandikdasmen. (2008). Spektrum Keahlian SMK. Jakarta: Ditjen Mandikdasmen.

DitPSMK. 2010. Roadmap DitPSMK 2010-2014. Jakarta: DitPSMK

Enco Mulyasa. (2002). Manajemen Berbasis Sekolah, Konsep, Strategi, dan Implementasi. Bandung: PT. Remaja Rosda Karya.

HB. Sutopo. (2002). Metode Penelitian Kualitatif. Surakarta: UNS Press.

Kemdiknas. (2010). Rencana Strategis Kementerian Pendidikan Nasional 20102014. Jakarta: Kemdiknas.

Kemdiknas. (2011). Rencana Kerja dan Anggaran Kemdiknas Tahun 2012. Jakarta: Kemdiknas.

Kunandar. (2007). Guru Profesional: Implementasi Kurikulum Tingkat Satuan Pendidikan dan sukses dalam sertifikasi. Jakarta: Raja Grafindo Persada

Majid, Abdul. (2005). Perencanaan Pembelajaran: Mengembangkan Standar Kompetensi Guru. Bandung: Remaja Rosdakarya.

Mulyasa. (2007). Menjadi Guru Profesional : Menciptakan Pembelajaran Kreatif dan
Menyenangkan. Bandung : Remaja Rosdakarya.

M. Furqon Hidayatullah, dkk. (2009). Pemetaan Guru SMK Wilayah Jawa Tengah, Nusa Tenggara Timur, dan Sulawesi Tenggara (Laporan Penelitian Hibah Kompetitif). Surakarta: UNS

Nana Syaodih, 1997. Pengembangan Kurikulum:Teori dan Praktek. Bandung : Remaja Rosdakarya.

Prosser, Charles A. \& Quigley, Thos H. (1950). Vocational Education in a Democracy. Chicago: American Technical Society.

Suyanto \& Abbas. (2001). Wajah dan Dinamika Pendidikan Anak Bangsa. Yogyakarta: Ade Cita Karya Nusa.

Sunyoto. (2009). Perluasan Sekolah Menengah Kejuruan dan Iimplikasinya terhadap Permintaan Guru. Semarang: UNNES.

Tilaar. H.A.R. (2004). Pendidikan Indonesia Masa Depan (Universitas dan Pendidikan Guru). Jakarta: UNJ Press.

Tim YPPTI. (2010). Reposisi dan Reorientasi Pendidikan Kejuruan Menjelang 2020. Jakarta: YPPTI

Uno, Hamzah. (2007). Model Pembelajaran: Menciptakan Proses Belajar Mengajar yang Kreatif dan Efektif. Jakarta: Bumi Aksara.

Wardiman Djojonegoro. (1998). Pengembangan Sumberdaya Manusia Melalui Sekolah Menengah Kejuruan (SMK). Jakarta: PT. Jayakarta Agung Offset.

Wasimudin Surya. (2008). Analisis Permintaan Tenaga Guru SMK untuk Memenuhi Proporsi SMK:SMA 70\%:30\%. Bandung: UPI Bandung

Yadi Mulyadi, dkk. 2010. Studi Evaluasi Permintaan Guru Sekolah Menengah Kejuruan Di Propinsi Bangka Belitung (Proceedings of The 4th International Conference on Teacher Education; Join Conference UPI \& UPSI Bandung, Indonesia, 8-10 November 2010)

Yoyon Bahtiar Irianto. (2011). Kebijakan Pembaruan Pendidikan. Jakarta: Rajawali Pers.

http://edukasi.kompasiana.com/2011/12/07/hakik at-kompetensi-guru/

http://www.blogguru.web.id/2011/04/desentralisasipendidikan-indonesia.html

http://bataviase.co.id/node/357958 
http//media.hariantabengan.com/index/detailiptek beritaphoto/id/ 14325)

http://arsipkorankita.blogspot.com/2009/11/prose s-penyediaan-guru-profesional.html.

http://www.blogguru.web.id/2011/04/desentralisasipendidikan-indonesia.html.

http://www.penyelarasan.kemdiknas.go.id/?panca dewa $=$ content\&id=20100508192653\&titl $\mathrm{e}=$ Kerangka-Kerja-Penyelarasan

http://www.pppgkes.com

http://www.psb-psma.org/content/blog/3793menggugat-desentralisasi-pendidikan

http://diksia.com/2011/03/kemdiknas-kaji-ulangdesentralisasi-pendidikan/ 